American Journal of Applied Sciences 7 (7): 859-877, 2010

ISSN 1546-9239

(C) 2010 Science Publications

\title{
Fish Spoilage Mechanisms and Preservation Techniques: Review
}

\author{
A.E. Ghaly, D. Dave, S. Budge and M.S. Brooks \\ Department of Process Engineering and Applied Science, \\ Dalhousie University Halifax, Nova Scotia, Canada
}

\begin{abstract}
Problem statement: Spoilage of food products is due to chemical, enzymatic or microbial activities One-fourth of the world's food supply and 30\% of landed fish are lost through microbial activity alone. With the ever growing world population and the need to store and transport the food from one place to another where it is needed, food preservation becomes necessary in order to increase its shelf life and maintain its nutritional value, texture and flavor. The freshness and quality of fish have always gained the attention by Food Regulatory Agencies and Food Processing Industry. Proper handling, pretreatment and preservation techniques can improve the quality fish and fish products and increase their shelf life. Methodology: Historically salting, drying, smoking, fermentation and canning were the methods to prevent fish spoilage and extend its shelf life. In response to consumer demand for texture, appearance and taste, new methods were developed including: Cooling, freezing and chemical preservation. A comprehensive review of the literature on the subject of fish spoilage and modern preservation techniques was carried out. Conclusion: Fish spoilage results from three basic mechanisms: Enzymatic autolysis, oxidation, microbial growth. Low temperature storage and chemical techniques for controlling water activity, enzymatic, oxidative and microbial spoilage are the most common in the industry today. A process involving the addition of an EDTA (1 mM)-TBHQ $(0.02 \%)$ combination and ascorbic acid and storage at refrigerated temperatures $\left(5^{\circ} \mathrm{C}\right)$ in darkness can be the most positive for controlling the spoilage of fish and fish product. The suggested process would address antimicrobial activity as well as destructive oxidation of the desired lipids and fats. However, more efforts are required to understand the role of proximate composition of fish, post harvest history, environmental conditions, initial microbial load, type and nature of bacteria and their interaction in order to optimize the shelf-life of fish.
\end{abstract}

Key words: Fish, spoilage, shelf-life, low temperature storage, chemical preservation

\section{INTRODUCTION}

With the ever growing world population and the need to store and transport the food from one place to another where it is needed, food preservation becomes necessary in order to increase its shelf life and maintain its nutritional value, texture and flavor. Therefore, good food preservation techniques must prevent microbial spoilage of food without affecting its quality and nutritional.

Kader (2005) and Harvey (1978) stated that about one third of all fruits and vegetables produced worldwide are lost due to spoilage. NAS (1978) estimated a $10 \%$ loss of cereals in developing countries. Kantor et al. (1997) conducted a detailed study on food losses in during total retail, foodservice and consuming in USA and reported total losses of 23, 24, 15 and 30\% for fruits, vegetables, meat, poultry and fish products and dairy products, respectively as shown in Table 1. Swanton et al. (1993) estimated the average annual cost of crop loss in Canada to be over $\$ 984$ million dollars. A value of $\$ 4$ billion of perishables food losses was estimated and more than $\$ 11$ billion of total food losses were also estimated in developing countries.

Spoilage of food products can be due to chemical, enzymatic or microbial activities. Chemical deterioration and microbial spoilage are responsible for loss of $25 \%$ of gross primary agricultural and fishery products every year (Baird-Parker, 2000). One-fourth of the world's food supply (Huis in't Veld, 1996) and 30\% of landed fish (Amos, 2007) are lost through microbial activity alone. Around 4-5 million tons of trawled and shrimp fish are lost every year due to enzymatic and microbial spoilage because of improper onsite storage (Unklesbay, 1992).

Corresponding Author: A.E. Ghaly, Department of Process Engineering and Applied Science, Dalhousie University, Halifax, Nova Scotia, Canada Tel: (902) 494-6014 
Am. J. Applied Sci., 7 (7): 859-877, 2010

Table 1: Food losses at retail, foodservice and consumer levels in USA in 1995 (Kantor et al., 1997)

\begin{tabular}{|c|c|c|c|c|c|c|}
\hline \multirow{3}{*}{$\begin{array}{l}\text { Commodity } \\
\text { Grain products }\end{array}$} & & \multirow{3}{*}{$\begin{array}{l}\text { Edible food supply } \\
\text { Million pounds } \\
\end{array}$} & \multicolumn{4}{|c|}{ Losses from edible food supply } \\
\hline & & & \multicolumn{2}{|l|}{ Retail food loss } & \multicolumn{2}{|c|}{ Food service and consumer food loss } \\
\hline & & & Million pounds & $(\%)$ & Million pounds & $(\%)$ \\
\hline & & 45,606 & 912 & 2 & 13,682 & 30 \\
\hline \multirow[t]{3}{*}{ Fruit } & Fresh & 22,389 & 448 & 2 & 6,717 & 30 \\
\hline & Processed & 25,949 & 259 & 1 & 3,892 & 15 \\
\hline & Total & 48,338 & 707 & 2 & 10,609 & 23 \\
\hline \multirow[t]{3}{*}{ Vegetables } & Fresh & 36,830 & 737 & 2 & 11,049 & 30 \\
\hline & Processed & 26,247 & 262 & 1 & 3,898 & 15 \\
\hline & Total & 63,077 & 999 & 2 & 14,947 & 24 \\
\hline \multirow[t]{4}{*}{ Meat, poultry and fish } & Red meat & 30,350 & 303 & 1 & 4,552 & 15 \\
\hline & Poultry & 17,108 & 171 & 1 & 2,566 & 15 \\
\hline & Fish and seafood & 4,008 & 40 & 1 & 601 & 15 \\
\hline & Total & 51,466 & 515 & 1 & 7,720 & 15 \\
\hline \multirow[t]{3}{*}{ Dairy products } & Fluid milk & 54,474 & 1,089 & 2 & 16,342 & 30 \\
\hline & Other & 21,802 & 436 & 2 & 6,541 & 30 \\
\hline & Total & 76,276 & 1,525 & 2 & 22,883 & 30 \\
\hline
\end{tabular}

Fresh fish spoilage can be very rapid after it is caught. The spoilage process (Rigor mortis) will start within $12 \mathrm{~h}$ of their catch in the high ambient temperatures of the tropics (Berkel et al., 2004). Rigor mortis is the process through which fish loses its flexibility due to stiffening of fish mussels after few hour of its death (Adebowale et al., 2008). Most fish species degrade as a result of digestive enzymes and lipases, microbial spoilage from surface bacteria and oxidation (AMEC, 2003). During fish spoilage, there is a breakdown of various components and the formation of new compounds. These new compounds are responsible for the changes in odour, flavor and texture of the fish meat.

This represents a major concern of the freshness of saleable products and the breakdown of proteins and lipids. Higher energy demanding freeze-storage preservation can be altered by synthetic or natural preservatives for control of lipid oxidation and microbial growth in fish during storage (Mahmoud et al., 2006). Combination of these preservatives and refrigeration diminishes the process of spoilage (Bagamboula et al., 2004).

Compositional changes during fish spoilage result in lipid oxidation and protein degradation as well as the loss of other valuable molecules. In order to develop optimum preservation techniques for these value added products in active forms, understanding of the mechanism responsible for their degradation is essential. This review will focus on basic mechanisms of fish spoilage, preservation of fish with low temperature storage and comprehensive analysis of chemical preservation methods.

\section{FISH SPOILAGE MECHANIZMS}

Fish spoilage results from three basic mechanisms: Enzymatic autolysis, oxidation, microbial growth.
Autolytic enzymatic spoilage: Shortly after capture, chemical and biological changes take place in dead fish due to enzymatic breakdown of major fish molecules (FAO, 2005). Hansen et al. (1996) stated that autolytic enzymes reduced textural quality during early stages of deterioration but did not produce the characteristic spoilage off-odors and off-flavors. This indicates that autolytic degradation can limit shelf-life and product quality even with relatively low levels of spoilage organisms. The autolytic changes that occur in chilled/frozen fish are summarized in Table 2 (FAO, 2005). Most of the impact is on textural quality along with the production of hypoxanthine and formaldehyde. The digestive enzymes cause extensive autolysis which results in meat softening, rupture of the belly wall and drain out of the blood water which contains both protein and oil (FAO, 1986).

A number of proteolytic enzymes are found in muscle and viscera of the fish after catch. These enzymes contribute to post mortem degradation in fish muscle and fish products during storage and processing. There is a sensorial or product associated alteration that can be contributed by proteolytic enzymes (Engvang and Nielsen, 2001). During improper storage of whole fish, proteolysis is responsible for degradation of proteins and is followed by a process of solubilization (Lin and Park, 1996). On the other hand, peptides and free amino acids can be produced as a result of autolysis of fish muscle proteins, which lead towards the spoilage of fish meat as an outcome of microbial growth and production of biogenic amines (Fraser and Sumar, 1998). Belly bursting is caused by leakage of proteolytic enzymes from pyloric caeca and intestine to the ventral muscle. The proteases have optimal $\mathrm{pH}$ in the alkaline to neutral range. Martinez and Gildberg (1988) reported that the rate of degradation by proteolytic enzymes was reduced when the fish was kept at $0^{\circ} \mathrm{C}$ and a pH of 5 . 
Am. J. Applied Sci., 7 (7): 859-877, 2010

Table 2: Summary of changes in chilled or frozen fish (FAO, 2005)

\begin{tabular}{|c|c|c|c|}
\hline Enzyme(s) & Substrate & Effect & Prevention \\
\hline Glycolytic enzymes & Glycogen & $\begin{array}{l}\text { Lactic acid production } \\
\text { resulting in } \mathrm{pH} \text { drop. }\end{array}$ & Avoid pre-rigor stress \\
\hline $\begin{array}{l}\text { Autolytic enzymes involved in nucleotide } \\
\text { breakdown }\end{array}$ & ATO, ADP, AMP, IMP & $\begin{array}{l}\text { Gradual production of } \\
\text { Hypoxanthine }\end{array}$ & $\begin{array}{l}\text { Avoid pre-rigor stress } \\
\text { and improved handling. }\end{array}$ \\
\hline Cathepsins & Proteins, peptides & Softening of tissue & Avoid rough handling during storage \\
\hline Chymotrypsin, trypsin, carboxy-peptidases & Proteins, peptides & Belly-bursting & $\begin{array}{l}\text { Problem increased with freezing/ } \\
\text { thawing or long-term chill storage }\end{array}$ \\
\hline Calpain & Myofibrillar proteins & Softening & Removal of calcium \\
\hline Collagenases & Connective tissue & $\begin{array}{l}\text { Softening and gaping of } \\
\text { tissue }\end{array}$ & $\begin{array}{l}\text { Time and temperature of chilled } \\
\text { storage }\end{array}$ \\
\hline Trimethylamine Oxide (TMAO) demethylase & TMAO & Formaldehyde & $\begin{array}{l}\text { Storage temperature less than }-30^{\circ} \mathrm{C} \text {, } \\
\text { physical abuse, freeze/thawing }\end{array}$ \\
\hline
\end{tabular}

Aoki and Ueno (1998) reported that the major cause of post-mortem degradation of mackerel muscle tissue was due to the activity of Cathepsin L. The enzyme was liberated from lysosomes during ageing for 7 days at $0^{\circ} \mathrm{C}$. The isolated enzyme was hydrolyzed to myosin, troponin $\mathrm{T}$, troponin I and tropomyosin. This hydrolytic action of mackerel cathepsin $\mathrm{L}$ was similar to that of cathepsin $\mathrm{L}$ from chum salmon white muscle as reported by Yamashita and Konagaya (1990). Yongsawatdigul et al. (2000) reported proteolytic degradation of tropical tilapia surimi when the temperature was increased beyond $40^{\circ} \mathrm{C}$ with a maximum activity at $65^{\circ} \mathrm{C}$. Due to inhibition by soybean trypsin inhibitor and leupeptin it was implied that the proteinase involved was serine proteinase.

Oxidative spoilage: Lipid oxidation is a major cause of deterioration and spoilage for the pelagic fish species such as mackerel and herring with high oil/fat content stored fat in their flesh (Fraser and Sumar, 1998). Lipid oxidation involves a three stage free radical mechanism: initiation, propagation and termination (Frankel, 1985; Khayat and Schwall, 1983). Initiation involves the formation of lipid free radicals through catalysts such as heat, metal ions and irradiation. These free radicals which react with oxygen to form peroxyl radicals. During propagation, the peroxyl radicals reacting with other lipid molecules to form hydroperoxides and a new free radical (Fraser and Sumar, 1998; Hultin, 1994). Termination occurs when a build up of these free radicals interact to form nonradical products. Oxidation typically involves the reaction of oxygen with the double bonds of fatty acids. Therefore, fish lipids which consist of polyunsaturated fatty acids are highly susceptible to oxidation. Molecular oxygen needs to be activated in order to allow oxidation to occur. Transition metals are primary activators of molecular oxygen (Hultin, 1994).

In fish, lipid oxidation can occur enzymatically or non-enzymatically. The enzymatic hydrolysis of fats by lipases is termed lipolysis (fat deterioration). During this process, lipases split the glycerides forming free fatty acids which are responsible for: (a) common offflavour, frequently referred to as rancidity and (b) reducing the oil quality (Huis in't Veld, 1996; FAO, 1986). The lipolytic enzymes could either be endogenous of the food product (such as milk) or derived from psychrotrophic microorganisms (Huis in't Veld, 1996). The enzymes involved are the lipases present in the skin, blood and tissue. The main enzymes in fish lipid hydrolysis are triacyl lipase, phospholipase A2 and phospholipase B (Audley et al., 1978; Yorkowski and Brockerhoft, 1965).

Non-enzymatic oxidation is caused by hematin compounds (hemoglobin, myoglobin and cytochrome) catalysis producing hydroperoxides (Fraser and Sumar, 1998). The fatty acids formed during hydrolysis of fish lipids interact with sarcoplasmic and myofibrillar proteins causing denaturation (Anderson and Ravesi, 1969; King et al., 1962). Undeland et al. (2005) reported that lipid oxidation can occur in fish muscle due to the highly pro-oxidative Hemoglobin $(\mathrm{Hb})$, specifically if it is deoxygenated and/or oxidized. They found that the addition of acids, which lower the $\mathrm{pH}$, can accelerate lipid oxidation through deoxygenated $\mathrm{Hb}$.

Microbial spoilage: Composition of the microflora on newly caught fish depends on the microbial contents of the water in which the fish live. Fish microflora includes bacterial species such as Pseudomonas, Alcaligenes, Vibrio, Serratia and Micrococcus (Gram and Huss, 2000) Microbial growth and metabolism is a major cause of fish spoilage which produce amines, biogenic amines such as putrescine, histamine and cadaverine, organic acids, sulphides, alcohols, aldehydes and ketones with unpleasant and unacceptable off-flavors (Dalgaard et al., 2006; Emborg et al., 2005; Gram and Dalgaard, 2002). For unpreserved fish, spoilage is a result of Gram-negative, fermentative bacteria (such as Vibrionaceae), whereas psychrotolerant Gram-negative bacteria (such as Pseudomonas spp. and Shewanella spp.) tend to spoil 
chilled fish (Gram and Huss, 2000). It is, therefore, important to distinguish non spoilage microflora from spoilage bacteria as many of the bacteria present do not actually contribute to spoilage (Huss, 1995). The compounds formed during spoilage through microbial metabolism are listed in Table 3.

Trimethylamine (TMA) levels are used universally to determine microbial deterioration leading to fish spoilage. Fish use Trimethylamine Oxide (TMAO) as an osmoregulant to avoid dehydration in marine environments and tissue waterlogging in fresh water. Bacteria such as Shewanella putrifaciens, Aeromonas spp., psychrotolerant Enterobacteriacceae, $P$. phosphoreum and Vibrio spp. can obtain energy by reducing TMAO to TMA creating the ammonia-like offflavors (Gram and Dalgaard, 2002). Table 4 lists spoilage bacteria in descending order of spoilage activity. Pseudomonas putrifaciens, fluorescent pseudomonads and other spoilage bacteria increase rapidly during the initial stages of spoilage, producing many proteolytic and hydrolytic enzymes (Shewan, 1961).

Table 3: Bacterial spoilage compounds (Church, 1998)

\begin{tabular}{|c|c|}
\hline Specific spoilage bacteria & Spoilage compounds \\
\hline Shewanella putrifaciens & TMA, $\mathrm{H}_{2} \mathrm{~S}, \mathrm{CH}_{3} \mathrm{SH},\left(\mathrm{CH}_{3}\right)_{2} \mathrm{~S}, \mathrm{HX}$ \\
\hline Photobacterium phosphoreum & TMA, HX \\
\hline Pseudomonas spp. & $\begin{array}{l}\text { Ketones, aldehydes, esters, non }-\mathrm{H}_{2} \mathrm{~S} \\
\text { sulphides }\end{array}$ \\
\hline Vibrionacaea & TMA, $\mathrm{H}_{2} \mathrm{~S}$ \\
\hline Aerobic spoilers & $\mathrm{NH}_{3}$, acetic, butyric and propionic acid \\
\hline $\begin{array}{l}\text { TMA: Trimethylamine; } \\
\text { Methylmercarptan; }\left(\mathrm{CH}_{3}\right)_{2} \mathrm{~S} \text { : } \\
\mathrm{NH}_{3} \text { : Ammonia }\end{array}$ & $\begin{array}{l}\mathrm{H}_{2} \mathrm{~S}: \quad \text { Hydrogen sulphide; } \mathrm{CH}_{3} \mathrm{SH} \\
\text { : Dimethylsulphide; } \mathrm{HX}=\text { Hypoxanthine }\end{array}$ \\
\hline \multicolumn{2}{|c|}{ Table 4: Spoilage activity of bacteria (Hui, 1992) } \\
\hline Spoilage activity & Microorganism \\
\hline High & $\begin{array}{l}\text { Pseudomonas (Alteronomas) putrifaciens } \\
\text { Pseudomonas (altreomonas) fluorescens } \\
\text { Fluorescent pseudomonads }\end{array}$ \\
\hline Moderate & Moraxella, Acinetobacter and Alcaligenes \\
\hline Low (Specific conditions) & $\begin{array}{l}\text { Aerobacter, Lactobacillus, Flavobacterium, } \\
\text { Micrococcus, Bacillus and Staphylococcus }\end{array}$ \\
\hline
\end{tabular}

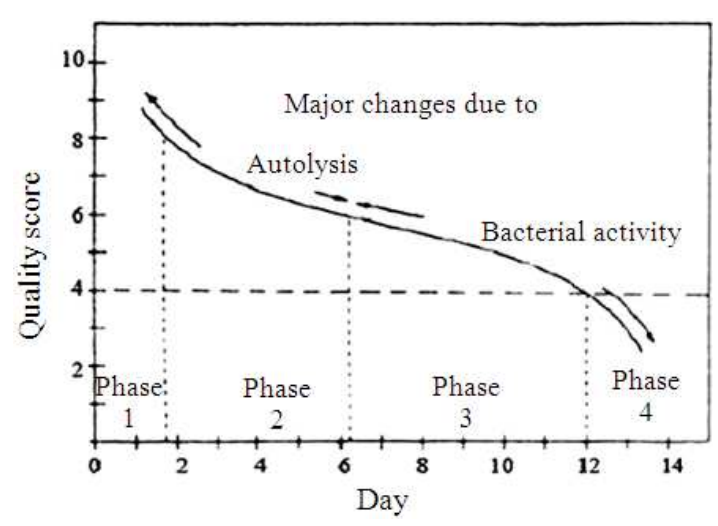

Fig. 1: The four phases of fish spoilage (Shawyer and Pizzali, 2003)
Liston (1980) stated that proteins are degraded by the proteases into peptides and amino acids, whereas lipids are degraded by lipases into fatty acids, glycerols and other compounds. Figure 1 illustrates spoilage of fish in four phases which starts form autolytic deterioration caused by enzymes and is responsible for initial first two phases of spoilage. The other two phases of spoilage result from the microbes, mainly bacteria which finally spoil the fish to such an extent that it cannot be edible (Abbas et al., 2009).

Olafsdottir et al. (2006) reported on the proliferation of specific spoilage organisms in haddock fillets stored at 0,7 and $15^{\circ} \mathrm{C}$ and found Photobacterium phosphoreum to be predominant among spoilage bacteria. Pseudomonas spp. appeared responsible for sweet, fruity spoilage odors while Shewanella putrefaciens was responsible for the $\mathrm{H}_{2} \mathrm{~S}$ production. Nuin et al. (2008) reported on the growth of spoilage bacteria on farmed turbot at temperatures of 0 and $15^{\circ} \mathrm{C}$. As shown in Fig. 2, Pseudomonas spp. showed the fastest growth at both temperatures and was considered responsible for turbot spoilage.


Fig. 2: Concentration of spoilage bacteria in farmed turbot: Line-Total aerobic bacteria, DashedPseudomonas spp. (Nuin et al., 2008) 
Am. J. Applied Sci., 7 (7): 859-877, 2010

\section{FISH PRESERVATION TECHNIQUES}

Different types of preservation methods such as drying, smoking, freezing, chilling, brining, fermentation and canning are reported to extend the self-life of seafoods and meat products. However, low temperature storage and chemical techniques for controlling water activity, enzymatic, oxidative and microbial spoilage are the most common in the industry today (Akinola et al., 2006; Berkel et al., 2004).

Low temperature storage: Since mid of 19th century, the low temperature storage method have been used for the preservation of wide varieties of seafood's which retard the growth of microorganisms. This method of preservation does not kill the microorganisms but reduces microbial metabolism which is responsible for spoilage (Ashie et al., 1996). Johnston et al. (1994) stated that freezing and cold storage are efficient methods of fish preservation but they do not improve product quality. It is necessary to preserve the fish at $0^{\circ} \mathrm{C}$ after catch as its spoilage is very rapid (FAO, 1973). Berkel et al. (2004) reported two possibilities for storing fresh fish at low temperatures: (a) cooling at $-1^{\circ}$ to $+4^{\circ} \mathrm{C}$, which inhibits the growth of microorganisms and (b) freezing at -18 to $-30^{\circ} \mathrm{C}$, which completely stops bacteria from growing. However, both enzymatic and non enzymatic changes continue but at a much slower rate.

The use of ice or other methods of chilling is recommended to keep the fish all times in a cool condition before freezing (Johnston et al., 1994). The functions of ice include: (a) maintaining uniform low temperature, (b) reducing autolysis and bacterial degradation and (c) providing a gentle washing/cleaning effect during melting (Rand and Pivarnik, 1992). In order to get the temperature below the freezing point of pure water, ice is made from saltwater to achieve a chilled temperature close to $-2.5^{\circ} \mathrm{C}$. However, a possible reduction of flavor due to loss of free amino acids may be a problem (Borgstrom, 1968). Freezing operation for preservation cannot ensure the prevention of amino acid losses. However, it surely impedes the physical and biochemical reactions which are responsible for spoilage of food (George, 1993). Survival of spoilage microorganisms during storage depends on the types of microorganisms and fish species, history of the fish, methods of catch and the handling and storage processes aboard the fishing vessel (Ashie et al., 1996).

Fish contains about $60-80 \%$ by weight water depending on the species. The process of freezing converts most of water into ice (Johnston et al., 1994).



Fig. 3: Percent of frozen water during freezing of fish at different temperatures (Johnston et al., 1994)

Even though freezing point of fish is -1 to $-2^{\circ} \mathrm{C}$, at a temperature of $-25^{\circ} \mathrm{C}$ only $90-95 \%$ of water freezes. This does not include bound water which is chemically bound to specific sites such as carbonyl and amino group of proteins and hydrogen bonding (Garthwaite, 1997). Johnston et al. (1994) reported on the variation of the proportion of water (which is converted to ice) in the muscle tissue of fish against temperature. As shown in Fig. 3, $70 \%$ of the water gets frozen at $-5^{\circ} \mathrm{C}$. However, at temperatures as low at $-30^{\circ} \mathrm{C}$, a proportion of the water in the fish muscle still remains in the unfrozen state. The final quality depends on the quality of the fish at the time of freezing as well as other factors including: freezing/cold storage temperature, freezing rate and distribution (Johnston et al., 1994).

The most crucial factor which affects the quality of frozen fish is the freezing rate (slow and fast). Fast freezing produces better quality frozen fish than slow freezing as slow freezing results in the formation of large ice crystals, in comparison to fast freezing, which damage the walls of the cells and cause denaturation of protein. On other hand, denaturation also depends on the concentration of enzymes and other compounds present (Rahman, 1999; Garthwaite, 1997; Johnston et al., 1994). The change of proteins results in dull and opaque textureand the tissue becomes soft and spongy which severely affects the quality of fish product (Graham, 1982).

The enzymatic reactions can still continue in frozen fish at a temperature of $-30^{\circ} \mathrm{C}$ (Cassens, 1994; Graham, 1982) which involve a number of other metabolites: Glycolysis, nucleotide degradation and proteolysis (Jones, 1963). These endogenous enzymatic activities cause intrinsic chemical and physical changes. 
Although enzymatic activities are slow, they can still support microbial growth and metabolism (Simpson, 1997). The cold storage life of some fish products at $-30^{\circ} \mathrm{C}$ is summarized by Graham (1982) in Table 5.

Microbial spoilage impedes at a recommended storage temperature of -9 to $-12^{\circ} \mathrm{C}$. However, enzyme present in the fish will still play an important part in spoilage. About $10-60 \%$ of the viable microbial population die during freezing yet the remaining population gradually increase during frozen storage (Rahman, 1999). Morlier et al. (1989) reported that Anasakis simplex, a nematode found in certain fish, can be killed by freezing to $-20^{\circ} \mathrm{C}$ and holding at least $24 \mathrm{~h}$. Raj and Liston (1961) reported that only a $1 \log _{10}$ reduction in numbers of Salmonella typhimurium when fish was frozen at $-22^{\circ} \mathrm{C}$ and stored at $-17.9^{\circ} \mathrm{C}$ for over 1 year. Miladi et al. (2008) found that freeze storage of L. monocytogenes in salmon does not decrease the potential survival of food-borne pathogens over a period of ten months at freezing temperature of $-20^{\circ} \mathrm{C}$. During cold storage, Thimethyalamine Oxide (TMAO) decomposition in fish and seafood results in to formation of trimethylamine and dimethyalamine which are responsible for off flavor (Hui, 2006) and formaldehyde reacts with proteins and is responsible for decreasing their solubility in salt and buffer solutions (Rahman, 1999). Arannilewa et al. (2005) investigated the effect of duration of freeze storage on the chemical, microbiological and sensory profile of tilapia fish (Sarotherodun galiaenus). They reported decreases in the values of protein and fat by 27.9 and $25.92 \%$, respectively. The total coliform count was increased from $3.0 \times 10^{3}-7.5 \times 10^{6}$ during storage.

The freezing of fish is achieved using different freezing methods. The basic principles include: Blowing cooled air over fish, placing fish in contact with cooled metal plate and by immersing fish in a low temperature liquid. The advantages and disadvantages of different methods are summarized in Table 6.

Controlling water activity: Although freezing is the best way to inhibit microbial growth (except psychrohpiles and spores) and slow chemical changes thereby preserving fish for a long time, it is an energy intensive operation and can only be used as a temporary method of preservation. Most of the psychrohpiles and spores survive during freezing and grow during thawing. Also, freezing does not prevent oxidative spoilage as enzymatic spoilage continues at slower rate (Neumeyer et al., 1997). Fish spoilage can be prevented by controlling water activity. For the growth of every microorganism there are minimum, optimum and maximum water activity same like $\mathrm{pH}$ and temperature. Therefore, lowering water activity $\left(a_{w}\right)$ can minimize putrefaction and improve preservation of fish (Abbas et al., 2009). The term water activity $\left(a_{w}\right)$ refers to the water which is not bound to food molecules and can support the growth of bacteria, yeasts and moulds (fungi). The water activity $\left(a_{w}\right)$ represents the ratio of the water vapor pressure of the food to the water vapor pressure of pure water under the same conditions and it is expressed as a fraction (CSIRO, 2005). The control of water activity in fish is accomplished by drying, adding chemicals, or a combination of both methods. Sugars and sodium chloride have been used to bind up the free water molecules and create an osmotic imbalance resulting in cell growth inhibition (Ray, 2004).

Table 5: The cold storage life of some fish products at $-30^{\circ} \mathrm{C}$ (Graham, 1982)

\begin{tabular}{ll}
\hline Item & Storage life (months) \\
\hline White fish (gutted) & 8.0 \\
White fish (smoked) & 7.0 \\
Herring (gutted) & 6.0 \\
Herring (ungutted) & 6.0 \\
Mackerel (gutted) & 6.0 \\
Mackerel (ungutted) & 6.0 \\
Kippers & 4.5 \\
Raw whole nephrops & 8.0 \\
Shelled nephrops & 8.0 \\
Cooked shucked mussels & 8.0 \\
Raw shrimp & 6.0 \\
Raw whole oysters & 6.0 \\
Scallop meat & 6.0 \\
Cooked shrimp & 6.0 \\
Cooked whole crab & 6.0 \\
Cooked whole lobster & 6.0 \\
Extracted crab meat & 4.0 \\
\hline
\end{tabular}

Table 6: Comparison of common freezing methods

\begin{tabular}{|c|c|c|c|}
\hline Freezing methods & Description & Advantages & Disadvantages \\
\hline Air blast freezer & $\begin{array}{l}\text { Materials are frozen by ventilated } \\
\text { cooled air while passing slowly } \\
\text { on moving belts in a tunnel }\end{array}$ & $\begin{array}{l}\text { Accept wide range of shapes and } \\
\text { sizes of materials to be frozen }\end{array}$ & $\begin{array}{l}\text { Easy to be used inefficiently and } \\
\text { incorrectly and running cost is high }\end{array}$ \\
\hline Plate freezer & $\begin{array}{l}\text { The article to be frozen is placed the } \\
\text { middle of two refrigerated plates }\end{array}$ & $\begin{array}{l}\text { ss power and occupies } \\
\text { an air blast freezer }\end{array}$ & $\begin{array}{l}\text { Poor contact between materials and plates } \\
\text { and is effective only on flat packages }\end{array}$ \\
\hline Immersion freezing & $\begin{array}{l}\text { Direct immersion of the material } \\
\text { into cold liquid environment }\end{array}$ & Very efficient & $\begin{array}{l}\text { Difficulties in finding suitable liquid which } \\
\text { has low freezing point and does not } \\
\text { contaminate food }\end{array}$ \\
\hline $\begin{array}{l}\text { Liquid nitrogen } \\
\text { freezing }\end{array}$ & $\begin{array}{l}\text { Using liquid nitrogen at } 196^{\circ} \mathrm{C} \text { to } \\
\text { - spray on the fish to be frozen }\end{array}$ & $\begin{array}{l}\text { Short freezing time; compact equipment } \\
\text { and low product weight loss }\end{array}$ & $\begin{array}{l}\text { High cost of liquid nitrogen and the potential } \\
\text { danger involved when using liquid nitrogen }\end{array}$ \\
\hline
\end{tabular}


Am. J. Applied Sci., 7 (7): 859-877, 2010

Table 7: Minimal water activity for sodium chloride and glycerol (Chirife, 1994)

\begin{tabular}{lll}
\hline Bacteria & Sodium chloride $\left(\mathrm{a}_{\mathrm{w}}\right)$ & Glycerol $\left(\mathrm{a}_{\mathrm{w}}\right)$ \\
\hline Clostridium botulinum $\mathrm{E}$ & 0.965 & 0.940 \\
Clostridium botulinum $\mathrm{A}$ & 0.955 & 0.935 \\
Clostridium perfringens & 0.947 & 0.930 \\
Vibrio parahaemolyticus & 0.933 & 0.910 \\
Lysteria monocytogenes & 0.920 & 0.900 \\
\hline
\end{tabular}

Table 8: Minimal water activity for $S$. aereus growth in various solutes (Ballesteros et al., 1993)

\begin{tabular}{ll}
\hline Solute & Minimal water activity $\left(\mathrm{a}_{\mathrm{w}}\right)$ \\
\hline Ethanol & 0.975 \\
Propylene glycol & 0.960 \\
Glycerol & 0.890 \\
Sucrose & 0.870 \\
Sodium chloride & 0.860 \\
\hline
\end{tabular}

Sperber (1983) reported that the minimum value of $\mathrm{a}_{\mathrm{w}}$ required for bacterial growth ranged from 0.99 for Moraxella/Acinetobacter type organism to 0.86 for Staphylococcus aureus. Since that time, hurdle technology emerged based on an application of combined preservative factors (called hurdles) to prevent microbial growth and enhance shelf-life (Leistner and Gorris, 1995). The most important hurdles used in food preservation are: temperature (high or low), water activity $\left(\mathrm{a}_{\mathrm{w}}\right)$, acidity $(\mathrm{pH})$, redox potential (Eh), preservatives (nitrite, sorbate, sulfite) and competitive microorganisms such as lactic acid bacteria (Leistner, 2000).

Chawla et al. (2006) reported a reduction in water activity of fresh lamb intestine from $0.95-0.80$ with the addition of $10 \%(\mathrm{w} / \mathrm{w})$ of sodium chloride as part of a hurdle technology. The major setback for the use of $\mathrm{m}$ elerates the development of lipid oxidation and thus sodium chloride is that its prooxidant activity which accelerates the development of lipid oxidation and thus the deterioration of value added products (Decker and $\mathrm{Xu}, 1998)$.

Chirife (1994) reported that the inhibitory effects of sucrose and sodium chloride on Staphylococcus aureus were primarily related to a lower water activity. $\mathrm{He}$ suggested that other solutes such as ethanol, propylene glycol, butylenes glycol and various polyethylene glycols may have antibacterial effects related mainly to interaction with membrane enzymes responsible for peptidoglycan synthesis. Table 7 compares the minimal water activity for growth of various pathogenic bacteria using sodium chloride or glycerol. In all cases sodium chloride is more inhibitory than glycerol. Ballesteros et al. (1993) reported that the minimal water activity for Staphylococcus aureus growth of various solutes ranged from 0.86-0.975 as shown in Table 8. They observed that solutes such as alcohol, diols and polyethylene glycols are able to inhibit growth at much higher water activity than sodium chloride and sucrose.

Controlling autolytic enzymatic spoilage: As the fish degradation process begins with autolytic activity, it is important to slow the action of the digestive enzymes to improve preservation. This can be accomplished by removing the enzymes or by developing techniques that inhibit their activities. Gutting of the fish immediately after capture can avoid the invasion of digestive tract proteases through the abdominal cavity to the tissue and prevent or slow degradation (Pedrosa-Menabrito and Regenstein, 1988).

Gutting: In order to remove the strong proteases from the digestive track, gutting of the fish immediately after catch is essential. This procedure needs to be performed properly in order to avoid contact of digestive enzymes into tissue (Pedrosa-Menabrito and Regenstein, 1988). It should be noted that many factors such as the age of the fish, the species, the amount of lipid, the catching ground and method of catch will determine weather gutting of fish could be advantageous or not. Fatty fish species such as herring, sardine and mackerel are susceptible to heavy autolytic degradation when caught just after feeding. However, the gutting of lean species such as cod, is compulsory (Huss, 1988). The increased stomach and gut content have accompanying increased levels of digestive enzymes (Pedrosa-Menabrito and Regenstein, 1988). The digestive enzymes leak out during post-mortem when the belly walls burst (Gildberg and Raa, 1980). Belly bursting can be limited if the fish are kept cool and processed (gutted) quickly after catching (Hobbs, 1982). However, there may be chances of bacterial cross-contamination of fish during the gutting procedure (Erkan and Ozden, 2006).

Addition of sodium chloride: Sodium chloride has shown the ability to inactivate autolytic enzymes in marine species. Reddi et al. (1972) reported the inactivation of cathepsin extracted from winter flounder using $5 \% \mathrm{NaCl}$ when incubated for $25 \mathrm{~h}$ at room temperature. They concluded that $\mathrm{NaCl}$ is an inactivator of catheptic activity, which may, also, control autolytic spoilage. The effect of $\mathrm{NaCl}$ on cathepsin is shown in Fig. 4.

Siringan et al. (2006) reported extensively on the autolytic activity of endogenous proteinases in Indian anchovy. They found that $25 \%(\mathrm{w} / \mathrm{w}) \mathrm{NaCl}$ reduced autolytic activity by $48 \%$ as shown in Fig. 5. Sen (2005) reported that $10 \%$ solution of sodium chloride inactivated the autolytic enzyme when deveind shrimp was blanched for 5 minutes at $80^{\circ} \mathrm{C}$. 
Klomklao et al. (2004) studied proteolytic activities of splenic extract from three tuna species: skipjack tuna (Katsuwonus pelamis), yellowfin tuna (Thunnus albacores) and tongol tuna (Thunnus tonggol). They reported that autolytic activitiescontinuously decreased as $\mathrm{NaCl}$ concentration increasedand no activity remained in the presence of $30 \%(\mathrm{w} / \mathrm{v}) \mathrm{NaCl}$ at $55^{\circ} \mathrm{C}$ and $\mathrm{pH} 9.0$.

Yongsawatdigul et al. (2000) reported that proteolysis of tilapia surimi decreased by about $76 \%$ compared to the control $(0 \% \mathrm{NaCl})$ when surimi was incubated in $1 \mathrm{M} \mathrm{NaCl}$ at $65^{\circ} \mathrm{C}$ for $1.5 \mathrm{~h}$ as shown in Fig. 6. However, Reddi et al. (1972) reported that increasing salt concentrations reduced catheptic activity, but enzymes were still active at salt levels relevant to smoked salmon.

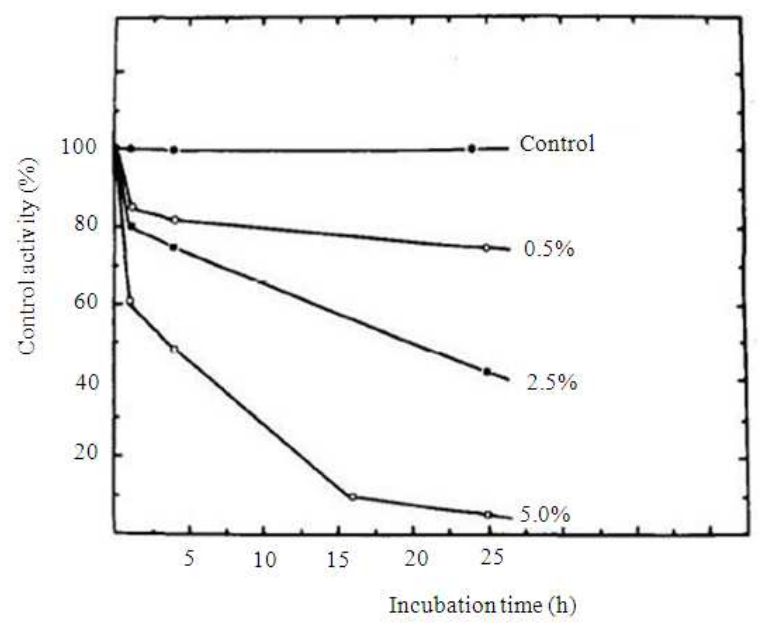

Fig. 4: The effect of $\mathrm{NaCl}$ on cathepsin (Reddi et al., 1972)

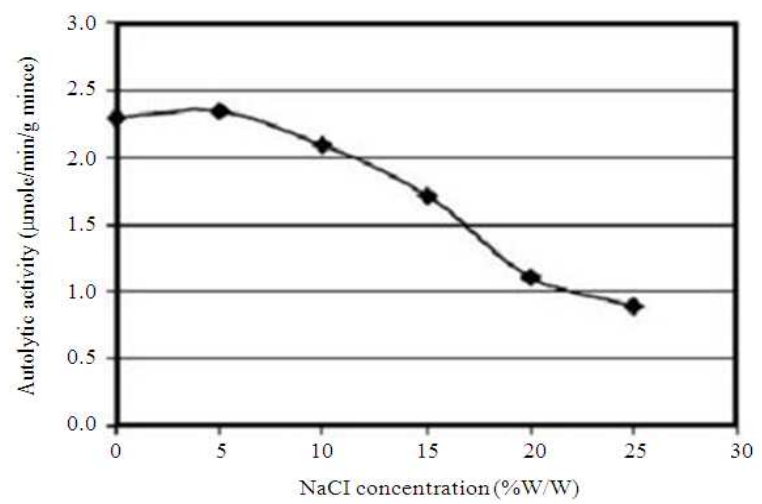

Fig. 5: Effect of $\mathrm{NaCl}$ on autolytic activity in Indian anchovy (Siringan et al., 2006)
Addition of acids: Martinez and Gildberg (1988) reported on the rate of Anchovy tissue degradation during storage with reduced $\mathrm{pH}$. The fish were stored in sea water at $1^{\circ} \mathrm{C}$ with the addition of lactic/acetic acid or propionic acid to lower the $\mathrm{pH}$ to 5 . After a storage period of $35 \mathrm{~h}$, they found that lactic acid was effective in reducing the percentage of belly bursting by half from $19-10 \%$ as illustrated in Table 9.

Hidalgo et al. (1999) conducted a comparative study of the proteolytic activities in six species of fish with different nutritional habits: Rainbow trout (Oncorhynchus mykiss), gilthead seabream (Sparus aurata) European eel (Anguilla anguilla), common carp (Cyprinus carpio), goldfish (Carassius auratus) and tench (Tinca tinca). When proteolytic activity was determined at a wide range of $\mathrm{pH}$ using $0.1 \mathrm{M} \mathrm{KCl}-\mathrm{HCl}$ (pH 1.5), $0.2 \mathrm{M}$ glycine-HCl (pH 3.0), $0.1 \mathrm{M}$ citrate (pH 4.0), 0.2 M phosphate ( $\mathrm{pH} 7.0), 0.1 \mathrm{M}$ Tris- $\mathrm{HCl}$ (pH 9.0) and 0.1 M glycine- $\mathrm{NaOH}\left(\mathrm{pH} \mathrm{10.0),} \mathrm{at} 25^{\circ} \mathrm{C}\right.$ ), the highest values in the digestive tract of all species were found at alkaline and neutral $\mathrm{pHs}$ as shown in Fig. 7. Only very low activity was observed at acidic pHs. An exceptional result was found in the case of eel where proteolytic activity was detected only at acidic pHs. However, Cabrer et al. (2002) reported that Cathepsin activity was increased in lower $\mathrm{pH}$ of marinated fish in acetic acid.

Controlling oxidative spoilage: To ensure maximum lipid yield, lipid oxidation and inhibition needs to be studied and understood. In order to inhibit lipid oxidation, the free radical mechanism catalysts (molecular oxygen and transition metals) need to be removed.

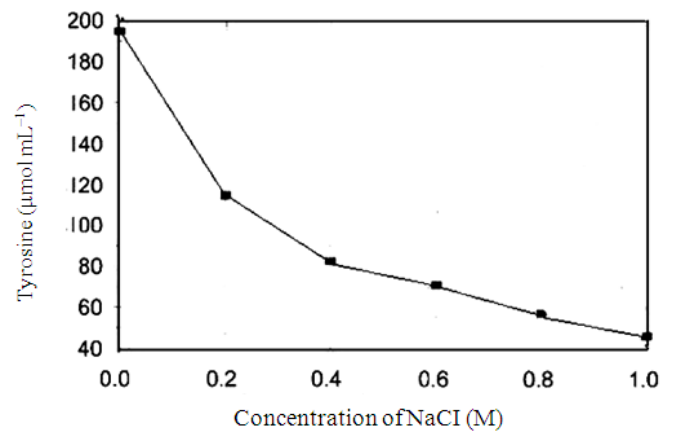

Fig. 6: Effect of $\mathrm{NaCl}$ concentration on autolytic activity of tilapia surimi at $65^{\circ} \mathrm{C}$ (Yongsawatdigul et al., 2000)

Table 9: Influence of acid addition on rate of belly bursting after 35 hrs of storage (Martinez and Gildberg, 1988)

\begin{tabular}{llll}
\hline Sample & Initial $\mathrm{pH}$ & Final $\mathrm{pH}$ & Belly bursting $(\%)$ \\
\hline Control $^{*}$ & 8 & 6.3 & 19 \\
Acetic acid & 5 & 5.9 & 11 \\
Lactic acid & 5 & 5.9 & 10 \\
Propionic acid & 5 & 5.9 & 13 \\
\hline
\end{tabular}



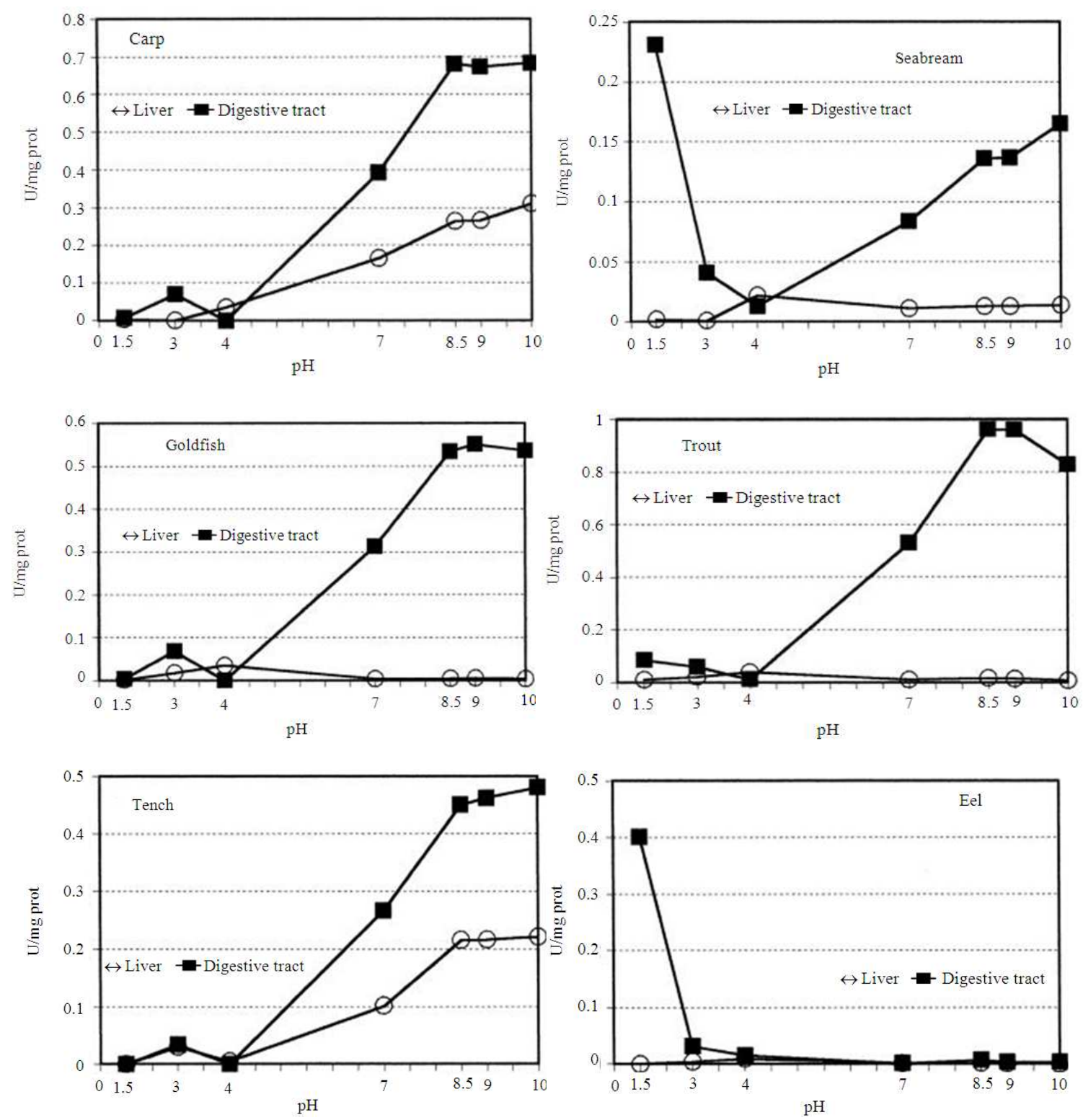

Fig. 7: $\mathrm{pH}$ dependence of the proteolytic activity in liver and digestive tract of the different species of fish (Hidalgo et al., 1999)

By removing these catalysts through antioxidants and chelating agents, lipid oxidation can be limited and the lipid yield improved. An index often used to determine lipid oxidation is the measurement of Thiobarbituric Acid Reactive Substances (TBARS). Among lipid oxidation inhibitory additives are: Phenolic antioxidants and ethylenediaminetetraacetic acid.

Phenolic antioxidants: Derivatives of phenol such as Butylated Hydroxyanisole (BHA), Butylated
Hydroxytoluene (BHT) and Tertiary Butylhydroquinone (TBHQ) are referred to as phenolic antioxidants (Davidson, 1993). BHA, BHT and TBHQ have antimicrobial properties against bacteria (predominately gram-negative), fungi, viruses and protozoa (Branen et al., 1980). According to Ray (2004), the antimicrobial activity is due to the adverse effects on cell membranes and enzymes. The antioxidant characteristics of the phenol-derivatives may be of greater benefit in terms of preservation. 
Am. J. Applied Sci., 7 (7): 859-877, 2010



(a)

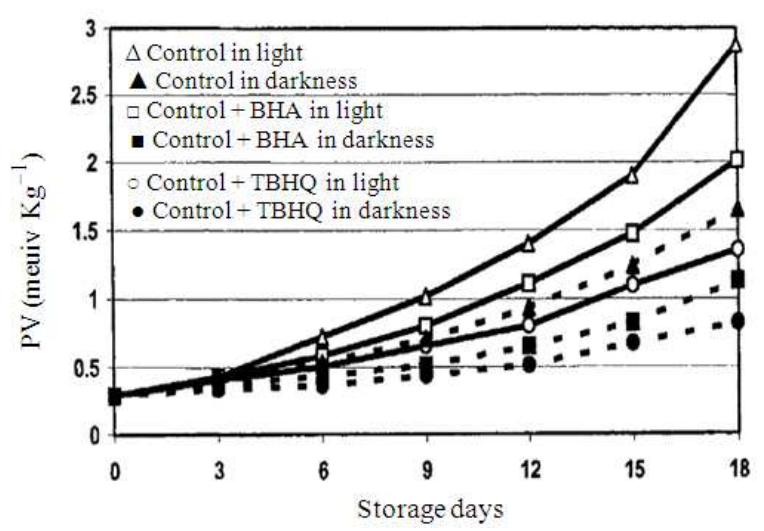

(b)

Fig. 8: Peroxide values for crude Mackerel oil during oxidation testing at (a) $5^{\circ} \mathrm{C}$ and (b) $40^{\circ} \mathrm{C}$ (Sang and Jin, 2004)

The antioxidant effectiveness in inhibiting oxidation may be in part due to the number of phenolic hydroxyl groups available for free radical scavenging (RiceEvans et al., 1996).

The Canadian Food and Drug Act limit the amount of phenolic antioxidants either singly or combined at $0.02 \%$ (DJC, 2009). Kaitaranta (1992) found that TBHQ (at $0.01 \%$ ) to be twice as effective in its antioxidative properties compare to BHA or BHT (at $0.02 \%$ ). TBHQ had an antioxidant efficiency value of 4.0 where BHA and BHT had values of 1.8 and 2.2, respectively. They, also, reported that during preliminary studies TBHQ had showed practically no measurable oxidation in the accelerated tests at levels higher than $0.02 \%$. Kelleher et al. (1992) reported similar results.

Sang and Jin (2004) reported on a combination of photo-oxidative stress and antioxidant activity of BHA and TBHQ in crude and refined Mackerel liver oil.



(a)

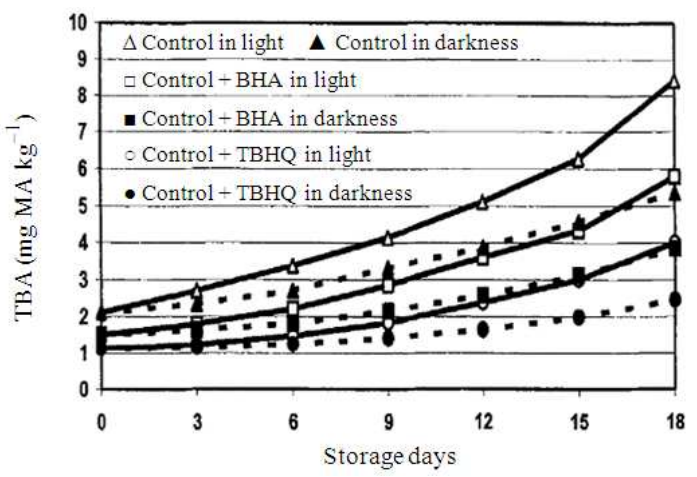

(b)

Fig. 9: TBA values for crude Mackerel oil during oxidation testing at (a) $5^{\circ} \mathrm{C}$ and (b) $40^{\circ} \mathrm{C}$ (Sang and Jin, 2004)

Changes in Peroxide Value (PV) and TBARS (thiobarbituric acid reactive substances) were monitored over 18 days at 5 and $40^{\circ} \mathrm{C}$. The peroxide value is used as an indicator of the extent of oxidative rancidity. It is affected by the age of raw material as well as oxidation of lipids during processing and storage (AMT, 1997). The results showed that exposure to visible light played the most critical role in oxidation followed by BHA and TBHQ. Figure 8 shows that peroxide values had the smallest increase with TBHQ at $200 \mathrm{ppm}$ stored in darkness. Figure 9 illustrates TBA values with the smallest increase again with TBHQ at $200 \mathrm{ppm}$ stored in darkness. It can also be seen in the figures that increase in storage temperature increased oxidation slightly.

Raghavan and Hultin (2005) reported on the effectiveness of phenolic antioxidants with haddock muscle samples. Figure 10 shows that the use of TBHQ on the haddock muscle samples stored on ice for a period of 12 days resulted in no oxidation and no painty odor (in terms of increased TBARS and sensory analysis, respectively) in comparison with BHA and BHT. 


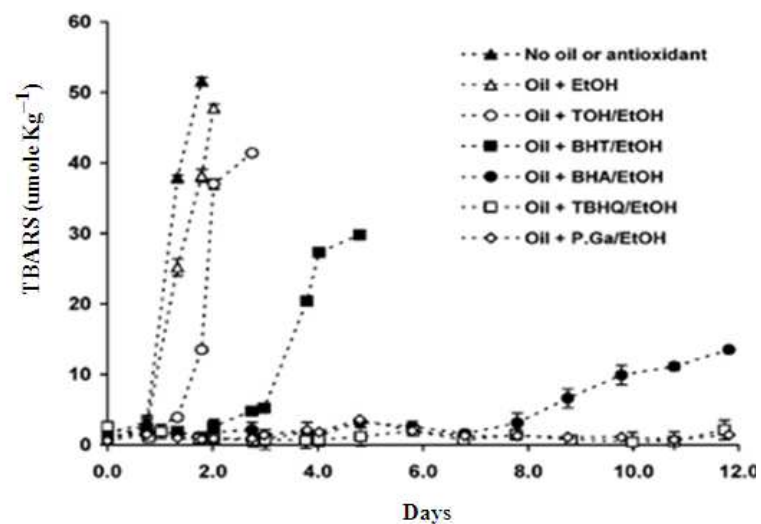

(a)

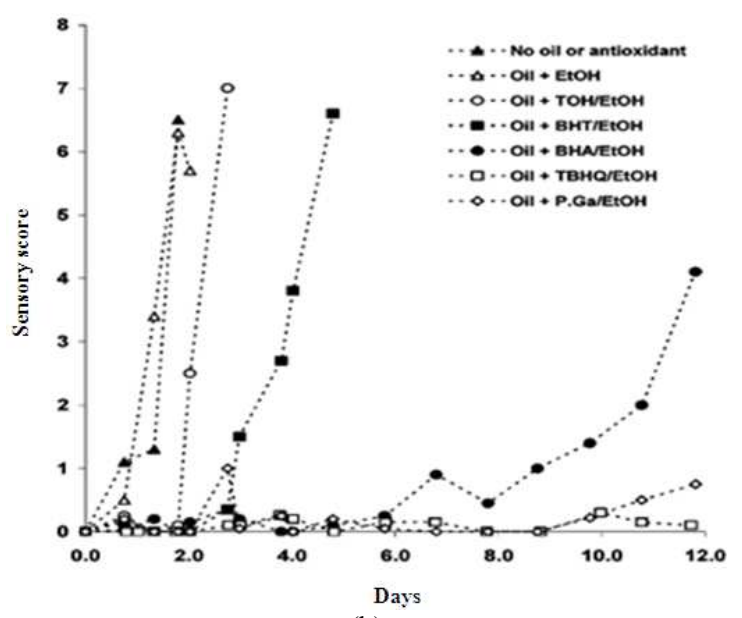

(b)

Fig. 10: (a) TBARS values (b) Sensory analysis of painty odor for haddock muscle stored on ice for 12 days (Raghavan and Hultin, 2005)

The effectiveness of the phenolic antioxidants was suggested as being largely influenced by the number of hydroxyl groups available for free radical scavenging. As TBHQ has two hydroxyl groups it gave the best performance over BHA and BHT which have one group.

\section{Ethylenediaminetetraacetic Acid (EDTA):} Ethylenediaminetetraacetic Acid (EDTA) is known as a chelating, sequestering and metal complexing agent (Shelef and Seiter, 2005). EDTA is a member of the polyaminocarboxylic acids group which can be added to fish to remove trace metals through chelation that may act as prooxidants. By removing these catalysts of the free radical mechanism, EDTA can be classified as a lipid oxidation inhibitor. It has, also, shown antimicrobial properties due to the binding of divalent cations found in bacterial cell walls (Shelef and Seiter, 2005).

As phenolic antioxidants have regulatory limits, they are only added during the grinding stage Shelef and Seiter (2005) used a 1\% EDTA solution dip to repress the growth of Pseudomonas species. Enhanced lipid oxidation inhibition occurred when the antioxidant mixture was added early in the processing during grinding and then again during washing and prior to storage. While recovering functional proteins from herring by an acid solubilization process, Undeland et al. (2005) found that the addition of EDTA $(0.044 \%, 1.5 \mathrm{mM})$ and erythorbate $(0.2 \%$, $9.3 \mathrm{mM}$ ) to herring fillets significantly reduced lipid oxidation. Kelleher et al. (1992) reported similar results.

Controlling microbial spoilage: Antimicrobial compounds can be found in food naturally formed during processing or added as an ingredient (Ray, 2004). If the antimicrobial is a food additive, it must qualify as being safe according to the specific country's legislation. In the United States, the additive must be GRAS-listed (Generally Recognized as Safe) according to the American Food and Drug Administration (FDA, 2009). In Canada, it must fall under GMP (Good Manufacturing Practice) in accordance with the Canadian Food and Drug Act (HC, 2006). Antimicrobials may be classified as direct or indirect based on the compound's properties and activity. Common antimicrobial compounds include: nitrites, sulfides and organic acids (Chipley, 2005; Ray, 2004; Archer, 2002).

Nitrites: Nitrites are usually added as salts (sodium nitrite or potassium nitrite) along with $\mathrm{NaCl}$, ascorbate and erythorbate to meat, poultry and fish products as an antimicrobial to the toxin producing Clostridium botulinum and to enhance color (Ray, 2004). Besides their exceptional antibacterial effect in controlling the anaerobic bacteria C. botulinum, Staphylococcus aureus, Yersinia enterocolitica, nitrite salts are extremely effective in controlling color, odor and lipid oxidation (Sindelar and Houser, 2009; Lovenklev et al., 2004; Archer, 2002; De Giusti and De Vito, 1992; Roberts, 1975). Although its antimicrobial mechanisms are not properly understood, it is known that nitrites may be involved in reactions with enzymes in vegetative cells and germinating spores, restricted use of iron by bacteria, limiting transport due to interference with membrane permeability (Ray, 2004).

It has been shown that the bactericidal nature is not that of nitrite alone but rather compounds derived from 
it during food preparation (Cammack et al., 1999). Nitrite antibacterial effect is enhanced at lower $\mathrm{pH}$ (56 ) and in the presence of reducing agents such as ascorbate and erythorbate (Ray, 2004). According to the US FDA, current regulatory limit for nitrite is 156 ppm (Ryser and Marth, 1999). In Canada, however, nitrite is limited to $200 \mathrm{ppm}$ in meat and marine mammals but prohibited as a fish additive (DJC, 2009). The cause for concern is associated with the possible formation of carcinogenic nitrosamines with prolonged exposure. However, no epidemiological study has shown a connection between nitrate/nitrite consumption and a specific cancer or cancer risk (Sindelar and Houser, 2009). Nitrosamine formation effects can be negated by addition of sodium ascorbate with nitrate and nitrite salts for the preservation of meat (Rywotycki, 2002; Mirvish et al., 1972).

Sulphites: The use of sulphiting agents to control undesirable microbial growth and activity is one of the oldest applications dating back at least to Roman times. Sulphur dioxide and the salts potassium bisulphite, potassium metabisulphite, sodium bisulphite, sodium metabisulphite and sodium sulphite are listed as GRAS in the US Code of Federal Regulations provided that they are not used in foods which are recognized as major dietary sources of thiamine (Walker, 1985).

Sodium sulfite is used as an antimicrobial agent in soft fruit, fruit juices, wines, beverages, sausages, pickles and fresh shrimp. Sulfides are effective against molds, yeasts and aerobic Gram-negative bacilli. The microbial activity is produced by the undissociated sulfurous acid which enters the cell and reacts with thiol groups of proteins, enzymes and cofactors (Ray, 2004).

Dyett and Shelley (1966) tested the effects of sulphite as preservative for meat sausages. The results indicated that the preservative had a significant inhibition effects on coli-aerogenes and other Gram negative microorganisms at room temperature. Omojowo et al. (2009) compared the salts of metabisulphite and sorbate with concentration of 1-3\% on the safety and shelf life of smoked catfish. They reported that both are good in reducing the E. coli and Streptococcus sp. They also found that potassium sorbate had no effect on Staphylococcus count throughout the period of storage while only $5 \%$ sodium metabisulphite was able to reduce the Staphylococcus count to 0 and remained 0 until the end of 8 th week storage.

The applications of sulphiting agents to meat and fish products are limited due to the destruction of thiamine (Walker, 1985). In UK, they may be applied to specified comminuted products such as fresh sausage in which they function primarily as antimicrobial agents, particularly in controlling Enterobacteriaceae including pathogenic Salmonellae (Banks and Board, 1982). Currently, sulfites are not permitted in Canada as meat or fish additives (DJC, 2009).

Lactic acid/lactates: Lactic acid has shown some antimicrobial properties when used as a rinse for beef, pork and chicken carcasses. This inhibitory capacity is due to the reduction in $\mathrm{pH}$ to levels where the bacteria cannot initiate growth (Doores, 2005). De Wit and Rombouts (1990) reported antimicrobial activity of sodium lactate $(5 \%)$ against various psychrotrophic lactic acid bacteria. Houtsma et al. (1993) reported extensively on the minimum inhibitory concentration of sodium lactate under optimal growth conditions $(\mathrm{pH}$ $6.5,20^{\circ} \mathrm{C}$ ) for bacteria isolated from spoiled and unspoiled meat products (Table 10). Tan and Shelef (2002) reported enhanced microbial stability in refrigerated fresh ground pork that was treated with a combination of sodium chloride $(1 \%, \mathrm{w} / \mathrm{w})$ and sodium lactate $(2 \%, \mathrm{w} / \mathrm{w})$.

Sallam (2007) evaluated the shelf life, chemical quality and sensory attributes of salmon slices treated by dipping in $2.5 \%$ aqueous solution of sodium Acetate $(\mathrm{NaA})$, sodium Lactate $(\mathrm{NaL})$, or sodium Citrate $(\mathrm{NaC})$ during refrigerated storage at $1^{\circ} \mathrm{C}$. He reported significant reduction in $\mathrm{K}$ value, Hypoxanthine $(\mathrm{Hx})$ concentration, Total Volatile Base Nitrogen (TVBN) and Trimethylamine (TMA) in treated salmon slices in terms of chemical analyses. A shelf life of 8, 12, 12 and 15 days was estimated for control and salmon treated with $\mathrm{NaL}, \mathrm{NaC}$ and $\mathrm{NaA}$, respectively.

Lactic acid bacteria are effective in inhabiting undesirable microorganisms in food by producing lactic acid and other organic acids (Matamoros et al., 2009). Matamoros et al. (2009) isolated several species of psychrotrophic lactic acid bacteria from various seafood products. Tome et al. (2008) succeeded in controlling growth of pathogenic Listeria monocytogenes using several lactic acid bacteria on cold-smoked salmon. The lactic acid bacteria strain Enterococcus faecium ET05 showed the best controlling results in the study.

Table 10: Minimum inhibitory concentration of sodium lactate (Houtsma et al., 1993)

\begin{tabular}{ll}
\hline & Minimum Inhibitory \\
Bacteria & Concentration (MIC) (mM) \\
\hline Salmonella spp. & $714-982$ \\
Lysteria monocytogenes and L. innocua & $804-982$ \\
Pseudomonas spp. and Yersinia spp. & $714-982$ \\
Campylobacter spp. & 179 \\
S. aureus and Lactobacillus coryniformis & 268 \\
Brochothrix & 804 \\
\hline
\end{tabular}


Park et al. (2005) assessed the antimicrobial effects of lactic acid producing bacteria culture condensate mixture on Salmonella enteritidis. At a concentration of 5 and $10 \%$ of culture condensate mixture, the growth of $S$. enteritidis was significantly retarded by observing the optical density of broth. However, their ability as inhabitors of pathogenic and spoilage bacteria needs to be investigated in practical use.

Ascorbic acid: Ascorbic acid (vitamin C), sodium ascorbateand D-isoascorbate (erythorbate) have been shown to enhance antimicrobial activity of sulfites and nitrites (Baird-Parker and Baillie, 1974; Raevuori, 1975). The enhanced activity is due to both the antioxidant properties as well as the sequestering of iron (Tompkin et al., 2007). It is commonly known thatPractice-listed with meats and fish (DJC, 2009). Ascorbate and its isomer (erythorbate) have antioxidant properties that oxidize reactive oxygen species producing water. Kelleher et al. (1992) and Undeland et al. (2005) stated that ascorbic acid has proven effective as an antimicrobial at $0.2 \%$.

Raevuori (1975) reported that the addition of 500 $\mathrm{mg} \mathrm{kg}-1$ of sodium erythorbate and $200 \mathrm{mg} \mathrm{kg}^{-1}$ sodium nitrite had prevented the growth of Bacillus cereus spores in sausages kept at $20^{\circ} \mathrm{C}$ for $48 \mathrm{~h}$. As previously mentioned, they also may inhibit the formation of carcinogenic nitrosamines which may form the use of nitrite (Mirvish et al., 1972). This finding resulted in the USDA limiting sodium nitrite input to $120 \mu \mathrm{g} \mathrm{g}^{-1}$ with the addition of $550 \mu \mathrm{g} \mathrm{g}^{-1}$ of sodium ascorbate or erythorbate (Tompkin, 2005). According to the Canadian Food and Drug Act, ascorbic acid and erythorbic acid are Good Manufacturing Practice-listed with meats and fish (DJC, 2009).

Benzoic acid: Benzoic acid and sodium benzoate are used as a preservative in products that are acidic in nature. Chipley (2005) states that benzoic acid and its salt are generally used to inhibit yeasts and fungi rather than bacteria. The benzoic acid stays as uncharged molecule under low $\mathrm{pH}$ conditions which is the form to readily cross the cell membrane. While once in the cytosol, the acid will dissociate because of basically neutral $\mathrm{pH}$ environment. The anion and protons released from original molecules cannot diffuse back across the membrane, hence accumulated in the cytosol. As a result, the acidification of the cytosol and the depletion of ATP as energy will cause physiological malfunction and finally inhibition of microorganism growth (Krebs et al., 1983; Warth, 1991; Brul and Coote, 1999; Hazan et al., 2004). The depletion of energy is mainly used in maintaining a lowered intracellular benzoate concentration (Warth, 1988).
However, according to Hazan et al. (2004), yeasts such as Saccharomyces and Zygosaccharomyces have intrinsic ability to resist benzoic acid under the tolerable toxicological limits. The combination of benzoic acid treatment and nitrogen starvation conditions is suggested by the author to enforce effective food preservation from yeast spoilage.

Efluvwevwere and Ajiboye (1996) conducted a study on control of microbial spoilage of smoked catfish by different chemical preservatives. They reported that sodium benzoate-treated samples could only be effective for the first 4 days after treatment under tropic environment. Van Spreekens (1977) reported that typical Pseudomonad-like shrimp-spoiling bacteria was inhibited by adding at least $0.8 \%$ benzoic acid as a preservative.

Dąbrowski et al. (2002) conducted a qualitative and quantitative studies on microflora of low-salt herring slices supplemented with $0,0.2$ and $0.3 \%$ of sodium benzoate (E-211). They observed that sodium benzoate reduced diversity of bacteria and yeasts in a tested product and exerted no influence on the total number of bacteria and yeasts. It gave the evidence that an empty ecological niche was created after elimination of some species by the preservative and the remainders substituted them.

In Canada, the limits set on benzoic acid are $1000 \mathrm{ppm}$ for marinated or similarly cold-processed packaged fish and meat. Alternatively, benzoic acid is not permitted for unstandarized meat and fish products (DJC, 2009).

\section{CONCLUSION}

The spoilage of fish and fish products depends on a number of factors. These factors as well as the spoilage mechanism must be thoroughly understand before developing proper handling and pretreatment methods and preservation techniques for food products. To stop the rapid spoilage of fish, it is essential to store the fish at $0^{\circ} \mathrm{C}$ after catching during harvesting. However, the energy intensive freezing operations is only a temporary method for preservation of fish as freeze storage can decrease microbial and enzymatic spoilage but cannot prevent oxidative spoilage. After a comprehensive review of current preservation techniques (which include: water activity; ant enzymatic, antimicrobial and ant oxidative techniques), a process involving the addition of an EDTA/TBHQ combination and ascorbic acid can be the most positive for controlling the spoilage of fish and fish product. The suggested process would address antimicrobial activity as well as destructive oxidation of the desired lipids and 
fats. The addition of EDTA ( $1 \mathrm{mM})$ and TBHQ (at the regulated level of $0.02 \%$ by weight of lipid content) have proven to be effective in limiting lipid oxidation and ascorbic acid has also proven effective as an antimicrobial at $0.2 \%$. Addition of preservative additives (EDTA/TBHQ/ascorbic acid) and storage at refrigerated temperatures $\left(5^{\circ} \mathrm{C}\right)$ in darkness could be the best possible way to preserve the fish and fish products. However, more efforts are required to understand the role of proximate composition of fish, post harvest history, environmental conditions, initial microbial load, type and nature of bacteria and their interaction in order to optimize the shelf-life of fish.

\section{ACKNOWLEDGMENT}

This research is supported by the National Science and Engineering Council (NSERC) of Canada through a Strategic Research Grant.

\section{REFERENCES}

Abbas, K.A., A.M. Saleh, A., Mohamed and O. Lasekan, 2009. The relationship between water activity and fish spoilage during cold storage: A review. J. Food, Agric. Environ., 7: 86-90.

Adebowale, B.A., L.N. Dongo, C.O. Jayeola and S.B. Orisajo, 2008. Comparative quality assessment of fish (Clarias gariepnius) smoked with cocoa pod husk and three other different smoking materials. J. Food Technol., 6: 5-8. DOI: 10.3923/jftech.2008.5.8

Akinola, O.A., A.A. Akinyemi and B.O. Bolaji, 2006. Evaluation of traditional and solar drying systems towards enhancing fish storage and preservation in Nigeria Abeokuta local government as a case study. J. Fisheries Int., 1: 44-49. DOI: $10.3923 /$ jfish.2006.44.49

AMEC., 2003. Management of wastes from Atlantic seafood processing operations. AMEC Earth and Environmental Limited, Dartmouth, Nova Scotia, Canada. http://aczisc.dal.ca/nparpt.pdf

Amos, B., 2007. Analysis of quality deterioration at critical steps/points in fish handling in Uganda and Iceland and suggestions for improvement. United Nations University, Uganda. http://www.unuftp.is/static/fellows/document/amos 06prf.pdf

AMT., 1997. Peroxide value. Meat Research Corporation, Australian Meat Technology. Australia.

http://www.meatupdate.csiro.au/data/Micro_Testin g_Advisory_Pack_15-98.pdf
Anderson, M.L. and E.M. Ravesi, 1969. Reactions of free fatty acids with protein in cod muscle frozen and stored at $-26^{\circ} \mathrm{C}$ after aging in ice. J. Fish Res., 26: $2727-2736$.

Aoki, T. and R. Ueno, 1998. Involvement of cathepsins $\mathrm{B}$ and $\mathrm{L}$ in the post-mortem autolysis of mackerel muscle. Food Res. Int., 30: 585-591. DOI: 10.1016/S0963-9969(98)00014-3

Arannilewa, S.T., S.O. Salawu, A.A. Sorungbe1 and B.B. Ola-Salawu, 2005. Effect of frozen period on the chemical, microbiological and sensory quality of frozen tilapia fish (Sarotherodun galiaenus). Afr. J. Biotechnol., 4: 852-855.

Archer, D.L., 2002. Evidence that ingested nitrate and nitrite are beneficial to health. J. Food Protect., 65: 872-875.

Ashie, I.N.A., J.P. Smith, B.K. Simpson and N.F. Haard, 1996. Spoilage and shelf-life extension of fresh fish and shellfish. Critical Rev. Food Sci. Nutr., 36: 87-121. DOI: 10.1080/10408399609527720

Audley, M.A., K.J. Shetty and J.E. Kinsella, 1978. Isolation and properties of phosphilase A from Pollock muscle. J. Food Sci., 43: 1771-1775. DOI: 10.1111/j.1365-2621.1978.tb07410.x

Bagamboula, C.F., M. Uyttendaele and J. Debevere, 2004. Inhibitory effect of thyme and basil essential oils, carvacrol, thymol, estragol, linalool and pcymene towards Shigella sonnei and S. flexneri. Food Microbiol., 21: 33-42.

Baird-Parker, A.C. and M.A.H. Baillie, 1974. The Inhibition of Clostridium botulinum by Nitrite and Sodium Chloride. Proceedings of the International Symposium on Nitrite in Meat Products, Sept. 1014, Wageningen, Pudoc, Zeist, The Netherlands, pp: 77.

Baird-Parker, T.C., 2000. The Production of Microbiologically Safe and Stable Foods. In: The Microbiological Safety and Quality of Food, Lund, B.M. and T.C. Baird-Parker (Eds.). Aspen Publishers Inc., Gaithersburg, MD., USA., ISBN: 0834213230, pp: 3-18.

Ballesteros, S.A., J. Chirife and J.P. Bozzini, 1993. Specific solute effects on Staphylococcus aereus cells subjected to reduced water activity. Int. J. Food Microbiol., 20: 51-66. DOI: 10.1016/01681605(93)90094-W

Banks, J.G. and R.G. Board, 1982. Sulphite-inhibition of Enterobacteriaceae including salmonella in British fresh sausage and in culture systems. J. Food Protect., 45: 1292-1297.

Berkel, B.M., B.V. Boogaard and C. Heijnen, 2004. Preservation of Fish and Meat. Agromisa Foundation, Wageningen, The Netherlands, ISBN: 90-72746-01-9 pp: 78-80. 
Borgstrom, G., 1968. Principles of Food Science: Food Technology. The Macmillan Company, New York, ISBN: 9543491087, pp: 206-241.

Branen, A.L., P.M. Davidson and B. Katz, 1980. Antimicrobial properties of phenolic antioxidants and lipids. Food Technol., 34: 42-53.

Brul, S. and P. Coote, 1999. Preservative agents in foods mode of action and microbial resistance mechanisms. Int. J. Food Microbiol., 50: 1-17. DOI: 10.1016/S0168-1605(99)00072-0

Cabrer, A.I., M.R. Casales and M.I. Yeannes, 2002. Physical and chemical changes in anchovy (Engraulis anchoita) flesh during marination. J. Aquatic Food Prod. Technol., 11: 19-30. DOI: 10.1300/J030v11n01_03

Cammack, R., C.L. Joannou, X.Y. Cui, C. Torres Martinez, S.R. Maraj and M.N. Hughes, 1999. Nitrite and nitrosyl compounds in food preservation. Biochimica et Biophysica Acta, 1411: 475-488. DOI: 10.1016/S0005-2728(99)00033-X.

Cassens, R.G., 1994. Meat Preservation, Preventing Losses and Assuring Safety. 1st Edn., Food and Nutrition Press, Inc., Trumbull, Connecticut, USA., ISBN: 0917678346, pp: 402-451.

Chawla, S.P., R. Chander and A. Sharma, 2006. Safe and shelf-stable natural casing using hurdle technology. Food Control, 17: 127-131. DOI: 10.1016/j.foodcont.2004.09.011

Chipley, J.R., 2005. Sodium Benzoate and Benzoic Acid. In: Antimicrobials in Food. 3rd Edn., Davidson, P.M., J.N. Sofos and A.L. Branen (Eds.). CRC Press, FL., ISBN: 924153026 X, pp: 11-48.

Chirife, J., 1994. Specific solute effects with special reference to Staphylococcus aereus. J. Food Eng., 22: 409-419. DOI: 10.1016/0260-8774(94)90043-4

Church, N., 1998. MAP fish and crustacean-sensory enhancement. Food Sci. Technol. Today, 12: 73-83.

CSIRO., 2005. Water Activity. CSIRO Food and Nutritional Sciences Fact Sheet. CSIRO Food and Nutritional Science, North Ryde, Australia. http://www.foodscience.afisc.csiro.au/water_fs.htm

Dąbrowski, W., K. Rozycka-Kasztelan, K. Czeszejko and D. Mędrala, 2002. Microflora of low-salt herring ii. The influence of sodium benzoate on microflora of low-salt herring. Elect. J. Polish Agric. Univ., $\quad 14$. http://www.ejpau.media.pl/volume5/issue2/food/art $-14 . h t m l$

Dalgaard, P., H.L. Madsen, N. Samieian and J. Emborg, 2006. Biogenic amine formation and microbial spoilage in chilled garfish (Belone belone) effect of modified atmosphere packaging and previous frozen storage. J. Applied Microbiol., 101: 80-95. DOI: $10.1111 / \mathrm{j} .1365-2672.2006 .02905 . x$
Davidson, P.M., 1993. Parabens and Phenolic Compounds. In: Antimicrobials in Food, Davidson, P.M. and A.L. Branen (Eds.)., 2nd Edn., Marcel Dekker, NY., ISBN: 0-8247-8906-7, pp: 291-304.

De Giusti, M. and E. de Vito, 1992. Inactivation of Yersinia entercolitica by nitrite and nitrate in food. Food Additives Contaminants, 9: 405-408. DOI: 10.1080/02652039209374091

De Wit, J.C. and F.M. Rombouts, 1990. Antimicrobial activity of sodium lactate. Food Microbiol., 7: 113-120. DOI: 10.1016/0740-0020(90)90017-C

Decker, E.A. and Z. Xu, 1998. Minimizing rancidity in muscle foods. Food Technol., 52: 54-59.

DJC., 2009. Food and Drug Act. Department of Justice, Canada. http://laws.justice.gc.ca/en/showtdm/cr/C.R.C.-c. 870

Doores, S., 2005. Organic Acids. In: Antimicrobials in Food. Davidson, P.M., J.N. Sofos and A.L. Branen (Eds.)., 3rd Edn., CRC Press, FL., ISBN: 0-82474037-8, pp: 91-142.

Dyett, E.J. and D. Shelley, 1966. The effects of sulphite preservative in British fresh sausages. J. Applied Bacteriol., 29: 439-446. DOI: 10.1111/j.13652672.1966.tb03495.x

Efluvwevwere, B.J.O. and M.O. Ajiboye, 1996. Control of microbiological quality and shelf-life of catfish (Clarias gariepinus) by chemical preservatives and smoking. J. Applied Bacteriol., 80: 465-470. DOI: 10.1111/j.1365-2672.1996.tb03244.x

Emborg, J., B.G. Laursen and P. Dalgaard, 2005. Significant histamine formation in tuna (Thunnus albacares) at $2^{\circ} \mathrm{C}$ : Effect of vacuum-and modifiedatmosphere-packaging on psychrotolerant bacteria. Int. J. Food Microbiol., 101: 263-279. DOI: 10.1016/j.ijfoodmicro.2004.12.001

Engvang, K. and H.H. Nielsen, 2001. Proteolysis in fresh and cold-smoked salmon during cold storage: Effects of storage time and smoking process. J. Food Biochem., 25: 379-395. 10.1111/j.17454514.2001.tb00747.x

Erkan, N. and O. Ozden, 2006. Gutted and un-gutted sea bass (Dicentrarchus labrax) stored in ice: Influence on fish quality and shelf-life. Int. J. Food Properties, 9: 331-345. DOI: 10.1080/10942910600596373

FAO., 1973. Code of practice for fresh fish. FAO Fisheries Circulation No. C318, Food and Agriculture Organization, Rome, Italy. http://www.fao.org/DOCREP/003/V3630E/V3630E03.htm

FAO., 1986. Fisheries Technical Papers-T142. The production of fish meal and oil. Fisheries Industries Division, Food and Agriculture Organization of the United Nations, Rome, Italy. http://www.fao.org/DOCREP/003/X6899E/X6899 E00.HTM 
FAO,, 2005. Post-harvest changes in fish. In: FAO Fisheries and Aquaculture Department, Food and Agriculture Organization, Rome, Italy. http://www.fao.org/fishery/topic/12320/en

FDA., 2009. Food. Generally Recognized as Safe (GRAS). U.S. Food and Drug Administration, USA. http://www.fda.gov/Food/FoodIngredientsPackagin g/GenerallyRecognizedasSafeGRAS/default.htm

Frankel, E.N., 1985. Chemistry of free radical and singlet oxidation of lipids. Progress. Lipid Res., 23: 197-221.

Fraser, O. and S. Sumar, 1998. Compositional changes and spoilage in fish. Nutr. Food Sci., 5: 275-279.

Garthwaite, G.A., 1997. Fish Processing Technology. In: Blackie Academic and Professional, Hall, G.M. (Ed.)., 2nd Edn., Chapman and Hall, London, UK., ISBN: 075140273 7, pp: 98.

George, R.M., 1993. Freezing processing used in food industry. Trends in Food Sci. Technol., 4: 134-138. DOI: 10.1016/0924-2244(93)90032-6

Gildberg, A. and J. Raa, 1980. Tissue Degradation and Belly Bursting in Capelin. In: Advances in Fish Science and Technology, Connell, J. (Ed.). Fishing News Books Ltd, England, ISBN: 10: 0852381085, pp: 255-258.

Graham, J., 1982. Cold Storage. In: Fish Handling and Processing, Aitken, A., I.M. Mackie, J.H. Merritt and M.L. Windsor (Eds.)., 2nd Edn., Tony Research Station, Edinburgh, UK., ISBN: 10: 0114917418, pp: 2-78.

Gram, L. and H.H. Huss, 2000. Fresh and Processed Fish and Shellfish. In: The Microbiological Safety and Quality of Foods, Lund, B.M., A.C. BairdParker and G.W. Gould (Eds.). Chapman and Hall, London, ISBN: 10: 0834213230, pp: 472-506.

Gram, L. and P. Dalgaard, 2002. Fish spoilage bacteriaproblems and solutions. Current Opinion Biotechnol., 13: 262-266. DOI: 10.1016/S09581669(02)00309-9

Hansen, T.L., T. Gill, S.D. Rontved and H.H. Huss, 1996. Importance of autolysis and microbiological activity on quality of cold-smoked salmon. Food Res. Int., 29: 181-186. DOI: 10.1016/09639969(96)00003-8

Harvey, J.M., 1978. Reduction of losses in fresh market fruits and vegetables. Annual Rev. Phytopathol., 16: 321-341. DOI: 10.1146/annurev.py.16.090178.001541

Hazan, R., A. Levine and H. Abeliovich, 2004. Benzoic acid, a weak organic acid food preservative, exerts specific effects on intracellular membrane trafficking pathways in Saccharomyces cerevisiae. Applied Environ. Microbiol., 70: 4449-4457. DOI: 10.1128/AEM.70.8.4449-4457.2004.
HC., 2006. Good manufacturing practices guidance document. Health Canada, Ottawa, Canada. http://www.hc-sc.gc.ca/dhp-mps/alt_formats/hpfb. dgpsa/pdf/prodnatur/gmp-bpf-eng.pdf

Hidalgo, M.C., E. Urea and A. Sanz, 1999. Comparative study of digestive enzymes in fish with different nutritional habits. Proteolytic and amylase activities. Aquaculture, 170: 267-283. DOI: 10.1016/S0044-8486(98)00413-X

Hobbs, G., 1982. Changes in Fish After Catching. In: Fish Handling and Processing, Aitkin, I.M. Mackie and J.H. Merritt (Eds.)., 2nd Edn., Tony Research Station, Edinburgh, UK., ISBN: 10: 0114917418, pp: $20-27$.

Houtsma, P.C., J.C. de Wit and F.M. Rombouts, 1993. Minimum Inhibitory Concentration (MIC) of sodium lactate for pathogens and spoilage organisms occurring in meat products. Int. J. Food Microbiol., 20: 247-257. DOI: 10.1016/01681605(93)90169-H

Hui, Y.H., 1992. Encyclopedia of Food Science and Technology. Willey-Interscience Publication, NY., ISBN: 10: 0471505412, pp: 870.

Hui, Y.H., 2006. Handbook of Food Science, Technology and Engineering. CRC Press, Boca Raton, FL., ISBN: 10: 0849398479, pp: 3632.

Huis in't Veld, J.H.J., 1996. Microbial and biochemical spoilage of foods: An overview. Int. J. Food Microbiol., 33: 1-18. DOI: 10.1016/01681605(96)01139-7

Hultin, H.O., 1994. Oxidation of Lipids in Seafoods. In: Seafoods Chemistry, Processing Technology and Quality, Shahidi, F. and J.R. Botta (Eds.)., 1st Edn., Blackie Academic and Professional, London, UK., ISBN: 10: 0751402184, pp: 49-74.

Huss, H.H., 1988. Fresh Fish: Quality and Quality Changes. FAO Fisheries Series No. 29, FAO, Rome, Italy, ISBN: 92-5-102395-6, pp: 132.

Huss, H.H., 1995. Quality and quality changes in fresh fish. FAO Fisheries Technical Paper 348, FAO, Rome, Italy. http://www.fao.org/DOCREP/V7180E/V7180E00.HTM

Johnston, W.A., Nicholson, F. J. and A. Roger, 1994. Freezing and refrigerated storage in fisheries. FAO Fisheries Technical Paper-T340, Rome, Italy. http://www.fao.org/DOCREP/003/V3630E/V3630 E00.HTM

Jones, N.R., 1963. Chemical change in fish muscle during storage. Proceed. Nutr. Soc., 22: 172-176. DOI: $10.1079 / \mathrm{PNS} 19630036$

Kader, A.A., 2005. Increasing food availability by reducing postharvest losses of fresh produce. Acta Horticulturae, 3: 2169-2176. 
Kaitaranta, J.K., 1992. Control of lipid oxidation in fish oil with various antioxidative compounds. J. Am. Oil Chemists' Soc., 69: 810-813. DOI: 10.1007/BF02635921

Kantor, L.S., K. Lipton, A. Manchester and V. Oliveira, 1997. Estimating and addressing America's food losses. Food Rev., 20: 3-11.

Kelleher, S.D., L.A. Silva, H.O. Hultin and K.A. Wilhelm, 1992. Inhibition of lipid oxidation during processing of washed, minced Atlantic mackerel. J. Food Sci., 57: 1103-1108. DOI: 10.1111/j.13652621.1992.tb11273.x

Khayat, A. and D. Schwall, 1983. Lipid oxidation in seafood. Food Technol., 37: 130-140.

King, F.J., M.L. Anderson and M.A. Steinberg, 1962. Reaction of cod actomyosin with linoleic and linolenic acids. J. Food Sci., 27: 363-366. DOI: 10.1111/j.1365-2621.1962.tb00107.x

Klomklao, S., S. Benjakul and W. Visessanguan, 2004. Comparative studies on proteolytic activity of splenic extract from three tuna species commonly used in Thailand. J. Food Biochem., 28: 355-372. DOI: $10.1111 / \mathrm{j} .1745-4514.2004 .05203 . \mathrm{X}$

Krebs, H.A., D. Wiggins and M. Stubbs, 1983. Studies on the mechanism of the antifungal action of benzoate. Biochem. J., 214: 657-663.

Leistner, L. and L.G.M. Gorris, 1995. Food preservation by hurdle technology. Trends Food Sci. Technol., 6: 41-46. DOI: 10.1016/S09242244(00)88941-4

Leistner, L., 2000. Basic aspects of food preservation by hurdle technology. Int. J. Food Microbiol., 55: 181-186. DOI: 10.1016/S0168-1605(00)00161-6

Lin, T.M. and J.W. Park, 1996. Protein solubility in Pacific whiting affected by proteolysis during storage. J. Food Sci., 61: 536-539. DOI: 10.1111/j.1365-2621.1996.tb13151.x

Liston, J., 1980. Microbiology in Fishery Science. In: Advances in Fish Science and Technology, Connel, J.J. (Ed.). Fishing News Books Ltd., Farnham, UK., ISBN: 10: 0852381085, pp: 138-157.

Lovenklev, M., I. Artin, O. Hagberg, E. Borch, E. Holst and P. Radstom, 2004. Quantitative interaction effects of carbon dioxide, sodium chloride and sodium nitrite on neurotoxin gene expression in nonproteolytic clostridium botulinum type B. Applied Environ. Microbiol., 70: 2928-2934. DOI: 10.1128/AEM.70.5.2928-2934.2004

Mahmoud, B.S.M., K. Yamazaki, K. Miyashita, I.I. Shin and T. Suzuki, 2006. A new technology of fish preservation by combined treatment with electrolysed $\mathrm{NaCl}$ solutions and essential oil compounds. Food Chem., 99: 656-662. DOI: 10.1016/j.foodchem.2005.08.037
Martinez, A. and A. Gildberg, 1988. Autolytic degradation of belly tissue in anchovy (Engraulis encrasicholus). Int. J. Food Sci. Technol., 23: 185-194. DOI: 10.1111/j.1365-2621.1988.tb00566.x

Matamoros, S., M. F. Pilet, F. Gigout, H. Prevost and F. Leroi, 2009. Selection and evaluation of seafood-borne psychrotrophic lactic acid bacteria as inhibitors of pathogenic and spoilage bacteria. Food Microbiol., 26: 638-644. DOI: 10.1016/j.fm.2009.04.011

Miladi, H., K. Chaieb, A. Bakhrouf, N. Elmnasser and E. Ammar, 2008. Freezing effects on survival of Listeria monocytogenes in artificially contaminated cold fresh-salmon. Annals Microbiol., 58: 471-476. DOI: $10.1007 / \mathrm{BF} 03175545$

Mirvish, S.S, L. Wallcave, M. Eagen and P. Shubik, 1972. Ascorbate-nitrite reaction: Possible means of blocking the formation of carcinogenic N-nitroso compounds. Science, 7: 65-68. DOI: 10.1126/science.177.4043.65

Morlier, D., S. Thiebault, G. Dalcher, B. Zeyer and J. Muller et al., 1989. A rare etiology of acute occlusion of the small intestine: Anisakiasis. Review of the literature apropos of a case. Annals Gastroenterol. Hepatol., 25: 99-103.

NAS., 1978. Post harvest food losses in developing countries. National Academy of Sciences, Washington, USA., pp: 8.

Neumeyer, K., T. Ross, G. Thomson and T.A. McMeekin, 1997. Validation of a model describing the effect of temperature and water activity on the growth of psychrotrophic pseudomonads. Int. J. Food Microbiol., 38: 55-63. DOI: 10.1016/S01681605(97)00090-1

Nuin, M., B. Alfaro, Z. Cruz, N. Argarate and S. George et al., 2008. Modeling spoilage of fresh turbot and evaluation of a Time-Temperature Integrator (TTI) label under fluctuating temperature. Int. J. Food Microbiol., 127: 193-199. DOI: 10.1016/j.ijfoodmicro.2008.04.010

Olafsdottir, G., H.L. Lauzon, E. Martinsdottir and K. Kristbergsson, 2006. Influence of storage temperature on microbial spoilage characteristics of haddock fillets (Melanogrammus aeglefinus) evaluated by multivariate quality prediction. Int. J. Food Microbiol., 111: 112-125. DOI: 10.1016/j.ijfoodmicro.2006.04.045

Omojowo, F.S. G.L. Idris and J.A. Ihuahi, 2009. Comparative Assessment of potassium sorbate and sodium metabisulphite on the safety and shelf life of smoked catfish. Nature Sci., 7: 10-17. 
Park, J.H., S.H. Seok, S.A. Cho, M.W. Baek and H.Y. Lee et al., 2005. Antimicrobial effect of lactic acid producing bacteria Culture Condensate Mixture (LCCM) against Salmonella enteritidis. Int. J. Food Microbiol., 101: 111-117. DOI: 10.1016/j.ijfoodmicro.2004.11.005

Pedrosa-Menabrito, A. and J.M. Regenstein, 1988. Shelf-life extension of fresh fish-A review-Part ISpoilage of fish. J. Food Qual., 11: 117-127.

Raevuori, M., 1975. Effect of nitrite and erythorbate on growth of Bacillus cereus in cooked sausage and laboratory media. Zentralbl Bakteriol Orig B, 161: 280-287.

Raghavan, S. and H.O. Hultin, 2005. Model system for testing the efficacy of antioxidants in muscle tissue. J. Agric. Food Chem., 53: 4572-4577. DOI: 10.1021/jf0501387

Rahman, S.F., 1999. Food Preservation by Freezing. In: Handbook of Food Preservation, Rahman, S.F. (Ed). Marcel Dekker, NY., ISBN: 0-8247-0209-3, pp: 258, 262, 268.

Raj, H. and J. Liston, 1961. Survival of bacteria of public health significance in frozen sea foods. Food Technol., 15: 429-434.

Rand, A.G. and L.F. Pivarnik, 1992. Enzyme Preservation of Fresh Seafoods. In: Advances in Seafood Biochemistry, Composition and Quality, Flick Jr., G.J. and R.E. Martin (Eds.)., 1st Edn., Technomic Publishing Co., Lancaster, USA., ISBN: 10: 0877629315, pp: 35-150.

Ray, B., 2004. Fundamental Food Microbiology. 3rd Edn., CRC Press, FL., ISBN: 0-8493-1610-3, pp: 439-534.

Reddi, P.K., S.M. Constantinides and H.A. Dymsza, 1972. Catheptic activity of fish muscle. J. Food Sci., 37: 643-648. DOI: 10.1111/j.13652621.1972.tb02716.x

Rice-Evans, C.A., N.J. Miller and G. Paganga, 1996. Structure antioxidant activity relationships of flavonoids and phenolic acids. Free Radical Biol. Med., 20: 933-956. DOI: 10.1016/08915849(95)02227-9

Roberts, T.A., 1975. The microbial role of nitrite and nitrate. J. Sci. Food Agric., 26: 1755-1760. DOI: 10.1002/jsfa.2740261118

Ryser, E.T. and E.H. Marth, 1999. Listeria, listeriosisand food safety. Marcel Dekker, NY., ISBN: 10: 0824702352, pp: 141.

Rywotycki, R., 2002. The effect of selected functional additives and heat treatment on nitrosamine content in pasteurized pork ham. Meat Sci., 60: 335-339. DOI: $10.1016 / \mathrm{S} 0309-1740(01) 00138-3$
Sallam, K.I., 2007. Chemical, sensory and shelf life evaluation of sliced salmon treated with salts of organic acids. Food Chem., 101: 592-600. DOI: 10.1016/j.foodchem.2006.02.019

Sang, W. and Z.T. Jin, 2004. Lipid oxidation of fish liver oil as affected by light, antioxidant and temperature. J. Food Process. Preservat., 28: 1-10. DOI: $10.1111 /$ j.1745-4549.2004.tb00533.x

Sen, D.P., 2005. Advances in Fish Processing Technology. Allied Publisher Private Limited, Mumbai, India, ISBN: 81-7764-655-9, pp: 448.

Shawyer, M. and M. Pizzali, 2003. The use of ice on Small Fishing Vessels. In: Food and Agriculture Organization of the United Nation, Shawyer, M. and M. Pizzali (Eds.). Rome, Italy, ISBN: 9251050104, pp: 1-34.

Shelef, L.A. and J. Seiter, 2005. Indirect and Miscellaneous Antimicrobials. In: Antimicrobials in Food, Davidson, P.M., J.N. Sofos and A.L. Branen (Eds.)., 3rd Edn., CRC Press, FL., ISBN: 10: 0824740378, pp: 11-48.

Shewan, J.M., 1961. The Microbiology of Sea-Water Fish. In: Fish as Food, Borgstrom, G. (Ed.). Academic Press, FL., pp: 487-560.

Simpson, B.K., 1997. Innovative Strategies for Controlling Fresh Fish Texture Degradation During Postharvest Handling and Storage, In: Seafood Safety, Processing and Biotechnology, F. Shahidi, Y. Jones and D.D. Kitts (Eds.). Technomic Publishing Co., Lancaster, USA., ISBN: 10: 1566765730, pp: 161-180.

Sindelar, J.J. and T.A. Houser, 2009. Alternative Curing Systems. In: Ingredients in Meat Products: Properties, Functionality and Applications, Tarte, R. (Ed.). Springer Science and Business Media, NY, pp: 379-405.

Siringan, P., N. Raksakulthai and J. Yongsawatdigul, 2006. Autolytic activity and biochemical characteristics of endogenous proteinases in Indian anchovy (Stolephorus indicus). Food Chem., 98: 678-684. DOI: 10.1016/j.foodchem.2005.06.032

Sperber, W.H., 1983. Influence of water activity on foodborne bacteria-A review. J. Food Protect., 46: $142-150$.

Swanton, C.J., K.N. Harker and R.L. Anderson, 1993. Crop losses due to weeds in Canada. Weed Technol., 7: 537-542.

Tan, W. and L.A. Shelef, 2002. Effects of sodium chloride and lactates on chemical and microbiological changes in refrigerated and frozen fresh ground pork. Meat Sci., 62: 27-32. DOI: 10.1016/S0309-1740(01)00223-6 
Tome, E., P.A. Gibbs and P.C. Teixeira, 2008. Growth control of Listeria innocua 2030c on vacuumpackaged cold-smoked salmon by lactic acid bacteria. Int. J. Food Microbiol., 121: 285-294. DOI: 10.1016/j.ijfoodmicro.2007.11.015

Tompkin, R.B., 2005. Nitrite. In: Antimicrobials in Food, Davidson, P.M., J.N. Sofos and A.L. Branen (Eds.)., 3rd Edn., CRC Press, FL., ISBN: 0824740378, pp: 169-236.

Tompkin, R.B., L.N. Christiansen and A.B. Shaparis, 2007. The effect of iron on botulinal inhibition in perishable canned cured meat. Int. J. Food Sci. Technol., 13: 521-527. DOI: 10.1111/j.13652621.1978.tb00833.x

Undeland, I., G. Hall, K. Wendin, I. Gangby and A. Rutgersson, 2005. Preventing lipid oxidation during recovery of functional proteins from herring (Clupea harengus) fillets by an acid solubilization process. J. Agric. Food Chem., 53: 5624-5634. DOI: $10.1021 / \mathrm{jf0} 0404445$

Unklesbay, N., 1992. World Food and You. Food Product Press, NY, ISBN: 1560220104, pp: 251.

Van Spreekens, K.J.A., 1977. Characterization of some fish and shrimp spoiling bacteria. Antonie van Leeuwenhoek, 43: 283-303. DOI: 10.1007/BF02313756
Walker, R., 1985. Sulphiting agents in foods: Some risk/benefit considerations. Food Addit. Contam., 2: 5-24. DOI: 10.1080/02652038509373522

Warth, A.D., 1988. Effect of benzoic acid on growth yield of yeasts differing in their resistance to preservatives. Applied Environ. Microbiol., 54: 2091-2095.

Warth, A.D., 1991. Mechanism of action of benzoic acid on Zygosaccharomyces effects on glycolytic metabolite levels, energy production and intracellular pH. Applied Environ. Microbiol., 57: 3410-3414.

Yamashita, M. and S. Konagaya, 1990. Participation of cathepsin $\mathrm{L}$ into extensive softening of the muscle of chum salmon caught during spawning migration. Nippon Suisan Gakkaishi, 56: 1271-1277.

Yongsawatdigul, J., J.W. Park, P. Virulhakul and S. Viratchakul, 2000. Proteolytic degradation of tropical tilapia surimi. J. Food Sci., 65: 129-133. DOI: $10.1111 /$ j.1750-3841.2000.00129.pp.x

Yorkowski, M. and H. Brockerhoft, 1965. Lyso lecthinase of cod muscle. J. Fish Res., 22: 643-652. 